\title{
Ukuran Perusahaan, Nilai Perusahaan, dan Pengungkapan CSR terhadap Manajemen Risiko dengan Good Corporate Governance sebagai Pemoderasi
}

\author{
Kadek Budi Suryanata ${ }^{1}$ \\ Fakultas Ekonomi dan Bisnis \\ Universitas Mataram, Indonesia. \\ Email: kbsuryanata@gmail.com \\ Endar Pituringsih ${ }^{3}$ \\ Fakultas Ekonomi dan Bisnis \\ Universitas Mataram, Indonesia.
}

\author{
Hermanto $^{2}$ \\ Fakultas Ekonomi dan Bisnis \\ Universitas Mataram, Indonesia.
}

\begin{abstract}
ABSTRAK
Penelitian bertujuan untuk menganalisis pengaruh ukuran perushaaan, nilai perusahaan, dan pengungkapan Corporate Social Responsibility (CSR) terhadap manajemen risiko dengan Good Corporate Governance (GCG) sebagai variabel moderasi. Populasi penelitian perusahaan manufaktur terdaftar di BEI tahun 2016-2018 yang mengungkapkan laporan tahunan dan laporan CSR. Sampel ditentukan dengan purposive sampling diperoleh 369 amatarn. Alat analisis data menggunakan Partial Least Square (PLS). Temuan penelitian menunjukan bahwa ukuran perusahaan dan pengungkapan CSR memilki pengaruh positif signifikan terhadap manajemen risiko dan GCG mampu menjadi pemoderasi antara interaksi pengungkapan CSR dan GCG terhadap manajemen risiko. Implikasi dari penelitian ini dapat berguna sebagai pertimbangan bagi perusahaan dalam membuat kebijakan yang memadai untuk meningkatkan kualitas manajemen risiko perusahaan guna meminimalisir risiko yang mengancam perusahaan.
\end{abstract}

Kata Kunci : Ukuran Perusahaan, Nilai Perusahaan, Pengungkapan CSR, GCG, Manajemen risiko.

\section{Firm Size, FirmValue, and CSR Disclosure of Risk Management with Good Corporate Governance as Moderating}

\section{ABSTRACT}

The research aims to analyze the effect of firm size, firm value, and Corporate Social Responsibility (CSR) disclosure on risk management with Good Corporate Governance (GCG) as a moderating variable. The research population of manufacturing companies was listed on the Indonesia Stock Exchange in 20162018 which revealed annual reports and CSR reports. Samples determined by purposive sampling obtained 369 samples. The data analysis tool uses Partial Least Square (PLS). The research findings show that firm size and CSR disclosure have a significant positive effect on risk management and GCG is able to moderate the interaction of CSR and GCG disclosure on risk management. The implication of this research can be useful as a consideration for companies in making adequate policies to improve the quality of corporate risk management in order to minimize risks that threaten the firm.

Keywords: Firm Size, Firm Value, CSR Disclosure, GCG, Risk Management.

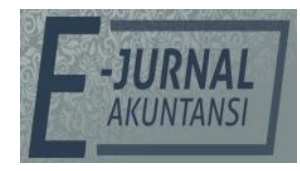

E-JA

e-Jurnal

Akuntansi

e-ISSN 2302-8556

Vol. 28 No. 3

September 2019

Hal. 2076-2095

Artikel masuk: 09 Agustus 2019

Tanggal diterima: 02 September 2019 


\section{PENDAHULUAN}

Manajemen risiko adalah suatu proses yang dibuat oleh manajemen perusahaan untuk mengelola risiko risiko yang mengancam perusahaan (Sulistyaningsih, 2016) Proses pembentukan manajemen risiko sendiri sangat dipengaruhi oleh risiko yang diperkirakan akan mengancam perusahaan. Secara umum risiko yang mengancam perusahaan di Indonesia adalah berupa perkembangan politik nasional maupun internasional dan ekonomi global selain itu perkembangan era bisnis yang terus berlanjut telah membawa juga telah membawa perubahan pada kompleksitas risiko-risiko yang akan dihadapi perusahaan.

Data pada Tabel 1. yang berasal dari Survei Nasional Manajemen Risiko 2018 melihat terdapat pergeseran jenis jenis risiko utama yang dihadapi oleh perusahaan semenjak tahun 2016 sampai dengan tahun 2018,

Tabel 1. Perkembangan Jenis Jenis Risiko

\begin{tabular}{|c|c|c|c|c|c|}
\hline Jenis Risiko (2016) & $\%$ & Jenis Risko (2017) & $\%$ & $\begin{array}{c}\text { Jenis Risiko } \\
(2018)\end{array}$ & $\%$ \\
\hline $\begin{array}{l}\text { Risiko Kerjasama } \\
\text { Dengan Pihak Ketiga }\end{array}$ & 41,8 & Risiko Reputasi & 43 & $\begin{array}{l}\text { Risiko Perubahan } \\
\text { Arah Perusahaan }\end{array}$ & 44,8 \\
\hline Risiko Reputasi & 40,8 & $\begin{array}{l}\text { Risiko Kegagalan } \\
\text { Perencanaan SDM }\end{array}$ & 39 & Risiko Reputasi & 44,8 \\
\hline $\begin{array}{l}\text { Risiko Perubahan } \\
\text { Arah Perusahaan }\end{array}$ & 40,3 & $\begin{array}{l}\text { Risiko Kebijakan } \\
\text { Pemerintah }\end{array}$ & 37 & $\begin{array}{l}\text { Risiko Kerjasama } \\
\text { Dengan Pihak } \\
\text { Ketiga }\end{array}$ & 40,7 \\
\hline Risiko Hukum & 36,3 & $\begin{array}{l}\text { Risiko Kerjasama } \\
\text { Dengan Pihak } \\
\text { Ketiga }\end{array}$ & 36 & $\begin{array}{l}\text { Ketidakpastian } \\
\text { Kebijakan } \\
\text { Pemerintah }\end{array}$ & 37,4 \\
\hline
\end{tabular}

Sumber : Survei Center Of Risk Management Studies 2018

Dapat dilihat pada Tabel 1. terdapat empat risiko terbesar yang dihadapi oleh perusahaan pada tahun 2016 yaitu risiko kerjasama dengan pihak ketiga $(41,8 \%)$, risiko reputasi $(40,8 \%)$, risiko perubahan arah perusahaan $(40,3 \%)$ dan risiko hukum (36,3\%). Pada tahun 2017, risiko reputasi merupakan risiko terbesar dengan jumlah $43 \%$, disusul dengan risiko kegagalan perencanaan sdm (39\%), ketidakpastian kebijakan pemerintah (37\%) dan risiko kerjasama dengan pihak ketiga (36). Di tahun 2018, empat jenis risiko yang mendapatkan persentase tertinggi sebagai risiko utama yang dihadapi perusahaan indonesia, yaitu risiko reputasi sebesar 44,8\% kemudian risiko reputasi $(44,8)$, Risiko Kerja sama dengan pihak ketiga (40,7\%) dan risiko ketidakpastian kebijakan pemerintah $(37,4 \%)$ yang menempati posisi ke-3 dan ke-4. Dapat kita lihat setiap tahunnya risiko utama yang mengancam perusahaan terus berubah hal ini membuat perusahaan harus mampu untuk menganalisis dan memberikan respon untuk menghadapi ancaman tersebut. Dari pihak eksternal, masyarakat semakin mudah mendapatkan akses informasi terutama yang berkaitan dengan bisnis dan perusahaan-perusahaan di Indonesia. Suatu kejadian yang menyangkut perusahaan baik itu positif maupun negatif akan semakin mudah diketahui oleh masyarakat. Dengan demikian, reputasi perusahaan penting untuk dijaga agar tetap positif. Di sisi lain, digitalisasi juga memaksa perusahaan untuk beradaptasi dengan perubahan dalam waktu singkat untuk mempertahankan keunggulan di industri. Untuk mengantisipasi 
ancaman dari risiko tersebut, tentu perusahaan harus mampu melakukan berbagai langkah strategis dan mitigasi terhadap perubahan-perubahan yang terjadi (CRSM, 2018).

Di Indonesia pernah terjadi kasus sebuah perusahaan akhirnya pailit akibat dari ketidakmampuan perusahaan dalam menganalisis dan mengolah risiko yang mengancam mereka dengan baik terjadi pada PT. Sariwangi Agricultural Estate Agency (Akbar, 2018). Penyebab utama dari pailitnya PT. Sariwangi Agricultural Estate Agency adalah gagalnya investasi yang dilakukan oleh perusahaan pada upaya untuk mengembangkan produksi mereka. Setelah Sariwangi mengeluarkan uang secara besar-besaran, ternyata hasil yang didapat tidak seperti yang Sariwangi harapkan. Sehingga pada akhirnya Sariwangi mengalami kesulitan dalam mengembalikan dana yang sebelumnya mereka pinjam untuk melakukan investasi tersebut (Wartakota.tribunnews, 2018).

Berkaca dari kasus yang terjadi pada PT. Sariwangi Agricultural Estate Agency, seharusnya perusahaan dapat mengambil sikap preventif terhadap risiko-risiko yang mengancam keberlangsungan hidup perusahaan yaitu dengan melakukan manajemen risiko. Proses manajemen risiko berkontribusi terhadap kesuksesan sebuah proyek dan menjadi bagian terintegrasi yang dievaluasi secara periodik. Sehingga, ke depannya, bilamana risiko serupa muncul lagi, perusahaan sudah mahir dalam mengantisipasi (Hanafi, 2014).

(Jensen \& Meckling, 1976) mengembangkan agency theory, yang menyatakan bahwa manajemen (sebagai agen) dan pemilik modal (sebagai principal) akan berusaha untuk memaksimalkan utilitasnya masing-masing melalui informasi yang dimiliki. Akan tetapi akibat dari agent yang memiliki informasi yang lebih banyak dibanding dengan principal dapat memicu para agent untuk melakukan tindakan-tindakan yang sesuai dengan keinginan dan kepentingan mereka untuk memaksimumkan utilitasnya tanpa memperhatikan risiko yang nantinya akan berpengaruh terhadap perusahaan. Pemilik modal dalam hal ini investor tentu akan sulit untuk mengontrol secara efektif tindakan yang dilakukan oleh manajemen karena hanya memiliki sedikit informasi yang ada. Hal ini lah yang menyebabkan para primcipal akan berusaha mengatasi permasalahan tersebut dengan melalukan pengawasan kepada manajemen dalam melakukan manajemen risiko.

Pada stakeholder theory yang diungkapkan oleh (Ghozali \& Chariri, 2007) menyatakan bahwa perusahaan bukanlah entitas yang hanya beroperasi untuk kepentingan perusahaan, namun juga harus memberikan manfaat bagi stakeholder (pemegang saham, kreditor, konsumen, pemasok, analis, karyawan, pemerintah, dan pihak lain seperti masyarakat yang merupakan bagian dari lingkungan sosial). Teori ini menjelaskan pentingnya perusahaan untuk memuaskan keinginan para stakeholder tersebut. Perusahaan akan bereaksi dengan melakukan aktivitas-aktivitas pengelolaan yang baik dan maksimal atas sumbersumber ekonomi untuk mendorong kinerja keuangan dan nilai perusahaan sesuai dengan harapan dari para stakeholder. Tujuan utama dari teori stakeholder adalah untuk membantu manajemen perusahaan dalam meningkatkan penciptaan nilai sebagai dampak dari aktivitas-aktivitas yang dilakukan dan meminimalkan kerugian yang ditimbulkan dari risiko risiko yang dihadapai oleh perusahaan yang mungkin muncul bagi stakeholder (Devi, 2017). 
Dalam menjalani bisnis, perusahaan harus benar-benar memperhatikan manajemen risiko. Semakin kecil potensi risiko bisnis, maka semakin aman bagi perusahaan dalam menjalankan usahanya. Kinerja manajemen risiko ini menjadi indikator penilaian di tingkat global untuk sejumlah perusahaan besar di Indonesia dan sejumlah negara lain (CRSM, 2013). Manajemen risiko dapat diartikan sebagai suatu proses yang dipengaruhi oleh manajemen perusahaan dan anggota lainnya yang diimplementasikan dalam setiap streategi perusahaan dan dirancang untuk memberikan keyakinan memadai agar dapat mencapai tujuan perusahaan, dan bertujuan untuk mengidentifikasi risiko perusahaan pada setiap kegiatan, serta mengukur dan mengatasinya pada level toleransi tertentu (COSO, 2018).

Penelitian tentang pengaruh ukuran perusahaan terhadap manajemen risiko telah dilakukan sebelumnya oleh Sanusi (2017) yang melakukan penelitian dengan melihat pengaruh ukuran perusahaan terhadap manajemen risiko. Dari hasil penelitian terlihat bahwa ukuran perusahaan berpengaruh positif signifikan dengan manajemen risiko karena semakin besar ukuran sebuah perusahaan maka semakin besar juga agency cost yang muncul sehingga perlu dilakukan manajemen risiko dengan melakukan pengawasan terhadap manajemen. Akan tetapi hasil temuan dari peneliti lain menemukan bahwa ukuran perusahaan tidak berpengaruh terhadap manajemen risiko seperti penelitian yang dilakukan oleh Khumairoh (2017) dikarenakan pihak manajemen diperusahaan besar lebih memilih mengalokasikan biaya manajemen risiko digunakan untuk pengembangan usaha.

Pada penelitian yang dilakukan oleh Eckles et al.,(2014) mengenai pengaruh nilai perusahaan terhadap manajemen risiko, ditemukan bahwa perusahaan yang memiliki nilai tinggi adalah perusahaan yang memiliki performa kinerja yang baik dengan kata lain perusahaan tersebut akan berhati hati dalam mengambil risiko ketika melakukan operasinya sehingga dapat disimpulkan bahwa perusahaan yang memiliki nilai tinggi maka manajemen risiko yang dimiliki oleh perusahaan juga tinggi. Akan tetapi hasil penelitian lain menemukan bahwa nilai perusahaan ternyata tidak ada pengaruhnya terhadap manajemen risiko perusahaan seperti penelitian yang dilakukan oleh Milos (2016) dikarenakan manajemen perusahaan menganggap bahwa pihak investor tidak terlalu begitu memperhatikan kinerja perusahaan melalui manajemen risiko yang dilakukan akan tetapi hanya melihat dari pengembalian yang akan mereka terima.

Kemudian pada penelitian yang dilakukan oleh Adiatma (2016) menemukan bahwa selain memiliki kemanfaatan secara sosial dan ekonomi pengungkapan CSR juga dianggap sebagai kewajiban yang mengandung biaya relatif besar yang justru hal ini akan berisiko mengganggu profitabilitas perusahaan secara langsung. Sehingga pada penelitiannya Adiatma (2016) menyimpulkan bahwa dengan semakin luas pengungkapan CSR yang dilakukan oleh perusahaan maka hal ini juga akan meningkatkan manajemen risiko yang dilakukan oleh perusahaan. Hasil penelitian ini berbeda dengan hasil peneltian yang dilakukan oleh Lee (2016) yang menemukan bahwa semakin tinggi kualitas pengungkapan CSR maka tingkat manajemen risiko dari perusahaan semakin lemah dikarenakan perusahaan sudah menganggap bahwa pengungkapan CSR merupakan salah satu cara perusahaan dalam mengelola risiko. 
Berjalan atau tidaknya manajemen risiko yang dilakukan oleh perusahaan sangat bergantung dengan praktek GCG yang telah diterapkan di dalam perusahaan. GCG merupakan praktek yang dilakukan oleh sebuah perusahaan dimana perusahaan berharap dengan melakukan praktek tersebut maka praktek tersebut akan menciptakan sebuah nilai yang nantinya akan membantu perusahaan dalam mencapai tujuan dari perusahaan dan perusahaan akan terus berada dalam pola pertumbuhan yang sehat dalam rentang waktu yang panjang. Dengan menerapkan GCG yang baik maka perusahaan dapat melakukan pengelolaan manajemen risiko yang baik di perusahaan untuk menghadapi risiko yang diperkirakan akan mempengaruhi perusahaan di masa yang akan datang seperti risiko pada aset perusahaan, kemudian nilai perusahaan dan aspek risiko pada pertanggungjawaban sosial perusahaan (CRSM, 2012).

Penelitian ini dilakukan termotivasi dari penelitian yang dilakukan oleh Khumairoh (2017) yang meneliti tentang manajemen risiko perusahaan. Perbedaan penelitian ini dengan penelitian sebelumnuya terletak pada variabel penelitian, dimana dalam penelitian sebelumnya meneliti tentang pengaruh kepemilikan institusional, kepekepemilikan manajerial, kepemilikan publik, ukuran perusahaan, dan leverage terhadap manajemen risiko perusahaan dengan ukuran dewan komisaris sebagai variabel moderasi. Sedangkan didalam penelitian ini terdapat variabel variabel baru yang diteliti, yaitu variabel independen berupa nilai perusahaan dan pengungkapan CSR serta variabel moderasi yaitu GCG

Nilai perusahaan dipilih sebagai variabel independen dikarenakan nilai perusahaan merupakan hal yang penting bagi perusahaan sebagai gambaran yang akan ditunjukan kepada investor akan keberhasilan perusahaan dalam melakukan kegiatan operasinya, dengan meningkatnya nilai perusahaan maka semakin meningkat pula manajemen risiko yang dilakukan oleh perusahaan (Eckles et al., 2014). Pengungkapan CSR dipilih sebagai variabel independen dikarenakan pengungkapan CSR ternyata dapat memunculkan risiko profitabilitas bagi perusahaan. Oleh karena itu risiko yang muncul akibat dari pengungkapan CSR perlu di atasi dengan melakukan manajemen risiko perusahaan guna menekan risiko yang ada.

GCG dipilih sebagai variabel moderasi dikarenakan GCG adalah sebuah mekanisme yang dijalankan oleh perusahaan serta diterapkan diseluruh aspek perusahaan untuk membantu berjalannya manajemen risiko perusahaan yang pada akhirnya akan menciptakan nilai tambah bagi perusahaan untuk mencapai tujuan akhir yang telah ditetapkan (CRSM, 2012). Selain itu originalitas dalam penelitian ini adalah memasukan agency theory dalam mendukung penjelasan pengaruh ukuran perusahaan terhadap manajemen risiko. Berdasarkan agency theory besarnya ukuran perusahaan juga akan meningkatkan agency cost yang terjadi di dalam perusahaan tersebut sehingga manajemen risiko di dalam perusahaan juga harus ditingkatkan.

Perusahaan manufaktur dipilih sebagai populasi penelitian ini dikarenakan kompleksnya kegiatan operasi perusahaan yang berawal dari penyediaan bahan baku sampai dengan pendistribusian barang jadi yang dipenuhi akan risiko, selain itu perusahaan manufaktur juga merupakan perusahaan yang melakukan kegiatan transaksi ekonomi dengan banyak pihak stakeholder yang tentu saja akan 
terdapat risiko pada hubungan akan masing-masing stakeholder tersebut (Ruwita, 2012). Penelitian ini akan dilakukan dengan melihat informasi di laporan tahunan perusahaan dan pengungkapan CSR yang diterbitkan di Bursa Efek Indonesia dan website masing-masing perusahaan mulai dari periode 2016 sampai dengan 2018.

Berdasarkan latar belakang masalah diatas maka tujuan dari ini adalah untuk menganalisis pengaruh ukuran perusahaan, nilai perusahaan, dan pengungkapan CSR terhadap manajemen risiko dengan GCG sebagai variabel moderasi.

Adapun Grand Theory yang mendasari penelitian ini adalah Agency Theory dan Stakeholder Theory. Teori keagenan atau agency theory menjelaskan hubungan keagenan yang timbul ketika satu orang atau lebih (principal) bersepakat dengan orang lain (agent) untuk memberikan jasa dan kemudian mendelegasikan wewenang pengambilan keputusan kepada agent tersebut (Jensen \& Meckling, 1976). Menurut Eisenhardt (1989), teori keagenan dilandasi oleh tiga asumsi. Asumsi yang pertama yaitu manusia selalu memiliki sifat untuk mementingkan diri sendiri (self interest), memiliki keterbatasan rasionalitas (bounded rationality), dan menghindari risiko (risk aversion). Kecenderungan mementingkan diri sendiri ini sering membuat konflik kepentingan antara agent dan principal. Asumsi selanjutnya adalah asimetri informasi, di mana agent memiliki lebih banyak informasi daripada principal karena mereka yang mengelola langsung sumber daya ekonomi. Menurut Jensen \& Meckling (1976), asimetri informasi menyebabkan dua masalah yaitu moral hazard dan adverse selection. Konfik kepentingan terjadi ketika manajemen tidak selalu bertindak untuk kepentingan pemilik. Masing-masing individu bertindak untuk memaksimalkan kepentingan sendiri sehingga agent yang lebih memiliki banyak informasi akan cenderung menyembunyikan informasi dari principal. Misalnya agent dapat mempengaruhi jumlah saldo akun tertentu dalam laporan keuangan dengan tujuan earning management. Masalah keagenan tentu dapat diatasi namun akan menimbulkan biaya keagenan (agency cost) yang ditanggung oleh principal mau pun agent. Dengan menerapkan manajemen risiko tentu hal ini dapat meminimalisir biaya keagenan.

Dalam stakeholder theory menjelaskan bahwa perusahaan tidak hanya beroperasi untuk pencapaian tujuannya saja tetapi harus memberikan manfaat bagi para stakeholder perusahaan. Stakeholder merupakan semua pihak baik internal maupun eksternal yang mempunyai hubungan yang bersifat mempengaruhi maupun dipengaruhi, bersifat langsung maupun tidak langsung oleh perusahaan. Menurut Clarkson (1994) terdapat dua golongan stakeholder yaitu stakeholder sukarela dan stakeholder non-sukarela.

Manajemen risiko yang dilakukan oleh perusahaan sangat berguna bagi para stakeholder untuk pengambilan keputusan dalam menanamkan saham. Manajemen risiko juga merupakan salah satu cara perusahaan untuk berkomunikasi dengan para stakeholder perusahaan. Melalui manajemen risiko dalam hal ini menampilkan profil risiko perusahaan, maka perusahaan dapat memberikan informasi khususnya informasi mengenai risiko yang terjadi di perusahaan. Dengan mengungkapkan informasi risiko secara lebih mendalam dan luas menunjukkan bahwa perusahaan berusaha untuk memuaskan kebutuhan 
akan informasi yang dibutuhkan oleh para stakeholder. Secara sistematis rerangka konseptual penelitian ini dapat dilihat pada Gambar 1.

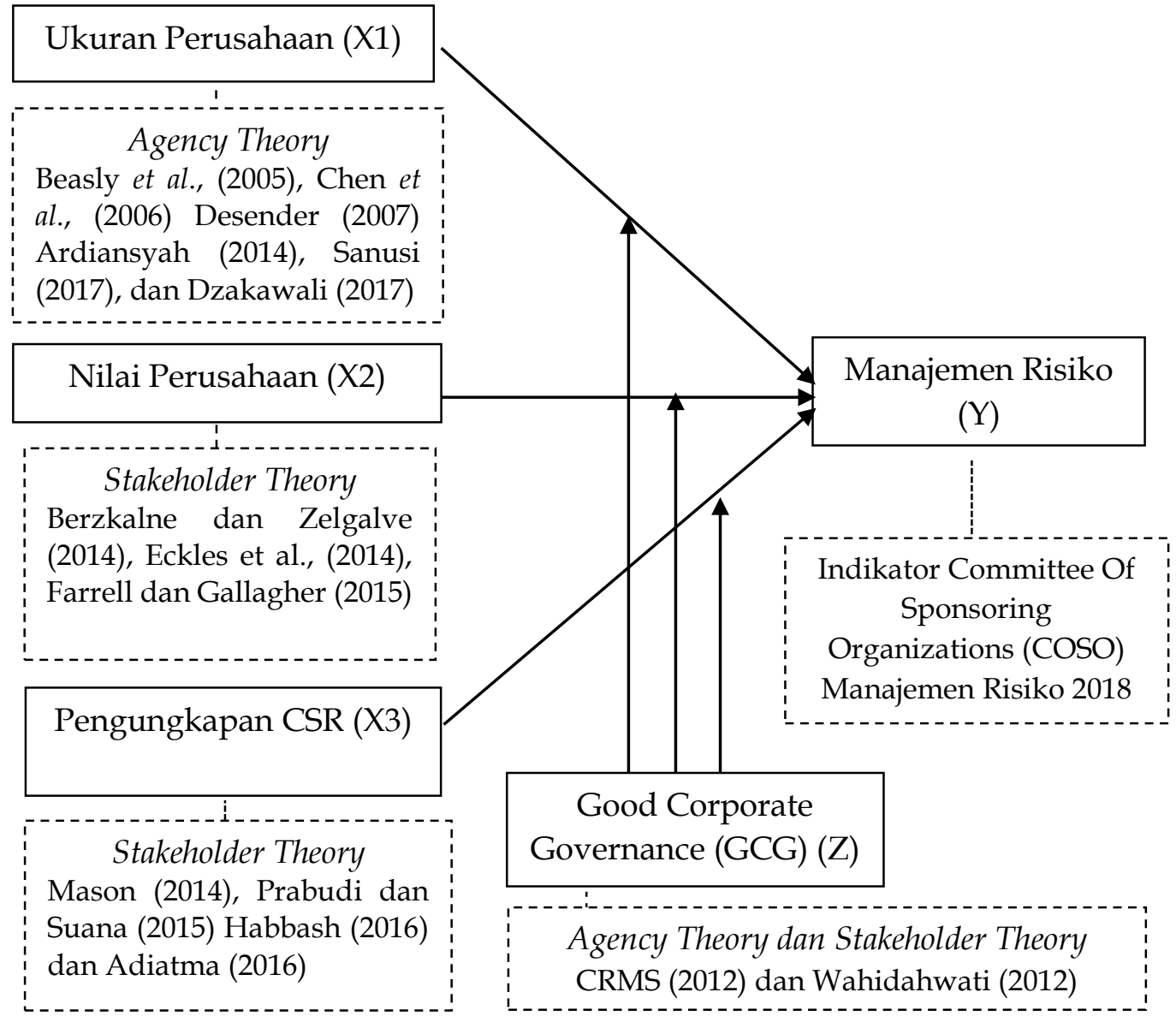

Gambar 1. Rerangka Konseptual Penelitian

Sumber : Data Penelitian, 2019

Penelitian sebelumnya yang dilakukan oleh Sanusi et al., (2017) menemukan bahwa semakin besar ukuran sebuah perusahaan maka semakin besar keleluasaaan manajemen untuk mengatur kegiatan operasional perusahaan salah satunya mempengaruhi saldo aset perusahaan, dengan demikian semakin besar ukuran sebuah perusahaan maka risiko munculnya agency cost juga semakin tinggi hal ini akan membuat perusahaan semakin meningkatkan manajemen risikonya. Penelitian mengenai pengaruh ukuran perusahaan terhadap manajemen risiko sebelumnya telah dilakukan oleh Beasley et al., (2005) dan Desender (2007), hasil dari penelitian penelitian tesebut menemukan bahwa ukuran perusahaan menunjukan pengaruhnya terhadap manajemen risiko.

$\mathrm{H}_{1}$ : Ukuran perusahaan berpengaruh positif terhadap manajemen risiko.

Dalam penelitian Eckles et al., (2014) menemukan bahwa perusahaan yang memiliki nilai perusahaan yang tinggi merupakan perusahaan yang memiliki performa kinerja yang tinggi dengan kata lain perusahaan yang sangat memperhatikan risiko apa saja yang akan dihadapi kira-kira oleh perusahaan ketika akan melakukan kegiatan operasinya sehingga diambil kesimpulan bahwa perusahaan yang memiliki nilai perushaan yang tinggi maka manajemen risiko 
yang dimiliki oleh perusahaan juga semakin kuat. Penelitian tentang pengaurh nilai perusahaan tehadap manajemen risiko sebelumnya telah dilakukan oleh Berzkalne \& Zelgave (2014), dan Farrell \& Gallagher (2015) yang hasilnya menunjukan bahwa nilai perusahaan berpengaruh terhadap manajemen risiko.

$\mathrm{H}_{2}$ : Nilai perusahaan berpengaruh positif terhadap manajemen risiko.

Pada penelitian yang dilakukan oleh Adiatma (2016) ditemukan bahwa selain memiliki kemanfaatan secara sosial dan ekonomi, pengungkapan CSR bagi perusahaan sendiri ternyata dianggap sebagai kewajiban yang mengandung biaya yang relatif besar yang justru hal ini akan berisiko mengganggu profitabilitas perusahaan secara langsung sehingga untuk meminimalisir risiko profitabilitas tersebut maka perusahaan akan meningkatkan manajemen risiko yang ada didalam perusahaan. Penelitian tentang pengaruh pengungkapan CSR dan manajemen risiko telah dilakukan oleh Mason \& John (2014), Prabudi \& Suana (2015) dan Habbash (2016) yang hasilnya menunjukan bahwa pengungkapan CSR memilki pengaruh terhadap manajemen risiko.

$\mathrm{H}_{3}$ : Pengungkapan Corporate Social Responsibility (CSR) berpengaruh positif terhadap manajemen risiko.

Besar kecilnya ukuran sebuah perusahaan dapat dilihat dari besarnya aset yang dimilki oleh perusahaan tersebut, semakin besar aset yang dikelola oleh perusahaan maka hal tersebut akan memunculkan potensi agency cost yang juga semakin tinggi maka kualitas manajemen risiko juga akan perlu ditingkatkan (Sanusi et al., 2017). Manajemen risiko yang telah dilakukan oleh perusahaan juga seharusnya dapat didukung dengan menerapkan praktek corporate governance dengan meningkatkan mekanisme GCG didalam perusahaan maka perusahaan dapat mengurangi risiko munculnya konflik keagenan yang pada akhirnya akan memunculkan agency cost yang semakin tinggi (Chen et al., 2006).

$\mathrm{H}_{4}$ : Good Corporate Governance (GCG) memperkuat pengaruh ukuran perusahaan terhadap manajemen risiko.

GCG memiliki pengaruh besar terhadap nilai perusahaan (Syafitri, 2018) dikarenakan GCG merupakan prinsip yang mengarahkan dan mengendalikan perusahaan agar mencapai keseimbangan antara kekuatan serta kewenangan perusahaan dalam memberikan pertanggungjawaban kepada pihak-pihak yang berkepentingan, shareholder pada khususnya dan stakeholder pada umumnya. Dengan adanya GCG yang pada akhirnya dapat mengurangi terjadinya manipulasi dalam informasi yang disajikan (Effendi, 2016).

$\mathrm{H}_{5}$ : Good Corporate Governance (GCG) memperkuat pengaruh nilai perusahaan terhadap manajemen risiko.

Pengungkapan CSR banyak dipengaruhi oleh beberpa faktor salah satunya GCG. Konsep GCG mulai dikenal di Indonesia sejak krisis ekonomi tahun 1997. Pada saat itulah GCG mencuat sebagai bentuk kontribusi pemerintah dalam upaya memperbaiki kondisi ekonomi Indonesia, seperti yang diungkapkan oleh Prabudi \& Suana (2015) pemerintah Indonesia menandatangani Nota Kesepakatan (Letter of Intent) dengan International Monetary Fund (IMF) yang mendorong terciptanya iklim yang lebih kondusif bagi penerapan GCG. Seiring berjalannya waktu GCG telah berperan dalam tingkat pengungkapan CSR yang dilakukan perusahaan, seperti yang diungkapkan Habbash (2015) mengungkapkan bahwa GCG telah berevolusi sebagai sarana yang mengakomodasi hal yang dulunya 
tidak dianggap perlu yaitu hubungan bisnis lingkungan dan hubungan bisnis masyarakat.

$\mathrm{H}_{6}$ : Good Corporate Governance (GCG) memperkuat pengaruh Pengungkapan Corporate Social Responsibility (CSR) terhadap Manajemen Risiko.

\section{METODE PENELITIAN}

Jenis penelitian yang digunakan pada penelitian ini adalah penelitian asosiatif deskriptif. Menurut Sugiyono (2013) Penelitian assosiatif merupakan suatu penelitian yang mencari hubungan antara dua variabel atau lebih. Penelitian ini dilakukan di Bursa Efek Indonesia (BEI) terhadap seluruh perusahaan manufaktur yang melaporkan laporan tahunan dari tahun 2016 sampai dengan 2018. Data diambil dari website seperti www.idx.co.id dan website perusahaan yang menjadi sampel.

Menurut Sugiyono (2013) mendifinisikan populasi sebagai wilayah generalisasi yang terdiri dari objek/subjek yang mempunyai kualitas dan karakteristik tertentu yang ditetapkan oleh peneliti untuk mempelajari dan kemudian ditarik kesimpulannya. Populasi dalam penelitian ini adalah seluruh perusahaan manufaktur yang terdaftar di Bursa Efek Indonesia yang menerbitkan laporan tahunan secara lengkap. Perusahaan manufaktur dipilih sebagai populasi penelitian ini dikarenakan kompleksnya kegiatan operasi perusahaan yang berawal dari penyediaan bahan baku sampai dengan pendistribusian barang jadi yang dipenuhi akan risiko, selain itu perusahaan manufaktur juga merupakan perusahaan yang melakukan kegiatan transaksi ekonomi dengan banyak pihak stakeholder yang tentu saja akan terdapat risiko pada hubungan akan masing masing stakeholder tersebut (Ruwita, 2012). Sedangkan sampel adalah bagian dari jumlah dan karakteristik yang dimiliki oleh populasi tersebut. Teknik pengambilan sampel dalam penelitian ini menggunakan pendekatan purposive sampling yaitu teknik pengambilan sampel dengan pertimbangan tertentu Sugiyono (2013). Purposive sampling digunakan karena data yang akan diambil berasal dari sumber yang sengaja dipilih berdasarkan kriteria yang telah ditetapkan peneliti.

\section{Tabel 2. Perhitungan Sampel}

\begin{tabular}{|c|c|c|c|}
\hline No & Kriteria & $\begin{array}{l}\text { Di Luar } \\
\text { Kriteria }\end{array}$ & Jumlah \\
\hline 1. & $\begin{array}{l}\text { Total perusahaan manufaktur yang terdaftar di } \\
\text { Bursa Efek Indonesia IDX selama periode 2016-2018 }\end{array}$ & & 151 \\
\hline 2. & $\begin{array}{l}\text { Perusahaan yang tidak memiliki informasi laporan } \\
\text { tahunan secara berkelanjutan selama periode 2016- } \\
2018 \text {. }\end{array}$ & (27) & 124 \\
\hline 3. & $\begin{array}{l}\text { Perusahaan yang tidak mencantumkan laporan CSR } \\
\text { didalam laporan tahunan maupun laporan secara } \\
\text { terpisah }\end{array}$ & (1) & 123 \\
\hline & Total sample $(123 \times 3)$ & & 369 \\
\hline
\end{tabular}

Sumber : Data Penelitian, 2019 
Variabel eksogen yaitu variabel yang tidak dipengaruhi oleh variabel lainnya dalam model penelitian ini. Terdapat 3 (tiga) variabel eksogen dalam penelitian ini, yaitu ukuran perusahaan yang diproksikan dengan Logaritma Natural (Kurniasih, 2013), nilai perusahaan diproksikan dengan Tobin's $Q$ (Prasetyoni, 2013) dan pengungkapan CSR diproksikan dengan menggunakan indikator GRI-G4 (Andhari, 2017). Variabel endogen yaitu variabel yang dipengaruhi oleh variabel lain dalam suatu penelitian. Variabel endogen dalam penelitian ini adalah manajemen risiko diproksikan dengan menggunakan indeks ERM COSO (Sulistyaningsih, 2016) .Variabel moderasi adalah variabel yang memperkuat atau memperlemah keberadaan suatu variabel. Variabel moderasi dalam penelitian ini adalah Good Corporate Governance (GCG) diproksikan dengan menggunakan Skoring GCG (Wahidahwati, 2012).

Alat analisis yang digunakan dalam penelitian ini adalah uji statistik inferensial dengan menggunakan Partial Least Square (PLS). Untuk gambar path diagram pada penelitian ini dapat dilihat pada Gambar 2. Sebelum pengolahan sebelum uji statistik inferensial dilakukan terlebih dahulu dilakukan uji linieritas untuk memastikan setiap variabel memilki hubungan liniear apabila uji liniear sudah terpenuhi maka pengujian hipotesis penelitian ini dilakukan dengan uji statistik inferensial. Persamaan model structural dalam penelitian ini adalah sebagai berikut:

$$
\begin{array}{ll}
\text { ManRes } & =\gamma_{1} \text { U_Per }+\gamma_{2} \text { N_Per }+\gamma_{3} C S R+\zeta 1 \ldots \ldots \ldots \ldots \ldots \ldots \ldots \ldots \\
\text { GCG } & =\beta 1 \text { U_Per }{ }^{*} G C G+\beta 1 N \_P e{ }^{*} G C G+\beta 3 \text { CSR }{ }^{*} G C G+\zeta 2
\end{array}
$$

Keterangan :

Y : Gamma, Koefisien pengaruh variabel eksogen terhadap variabel endogen

$\beta$ : Beta, Koefisien pengaruh variabel eksogen dengan variabel moderasi

$\zeta$ : Zeta, Galat model struktural

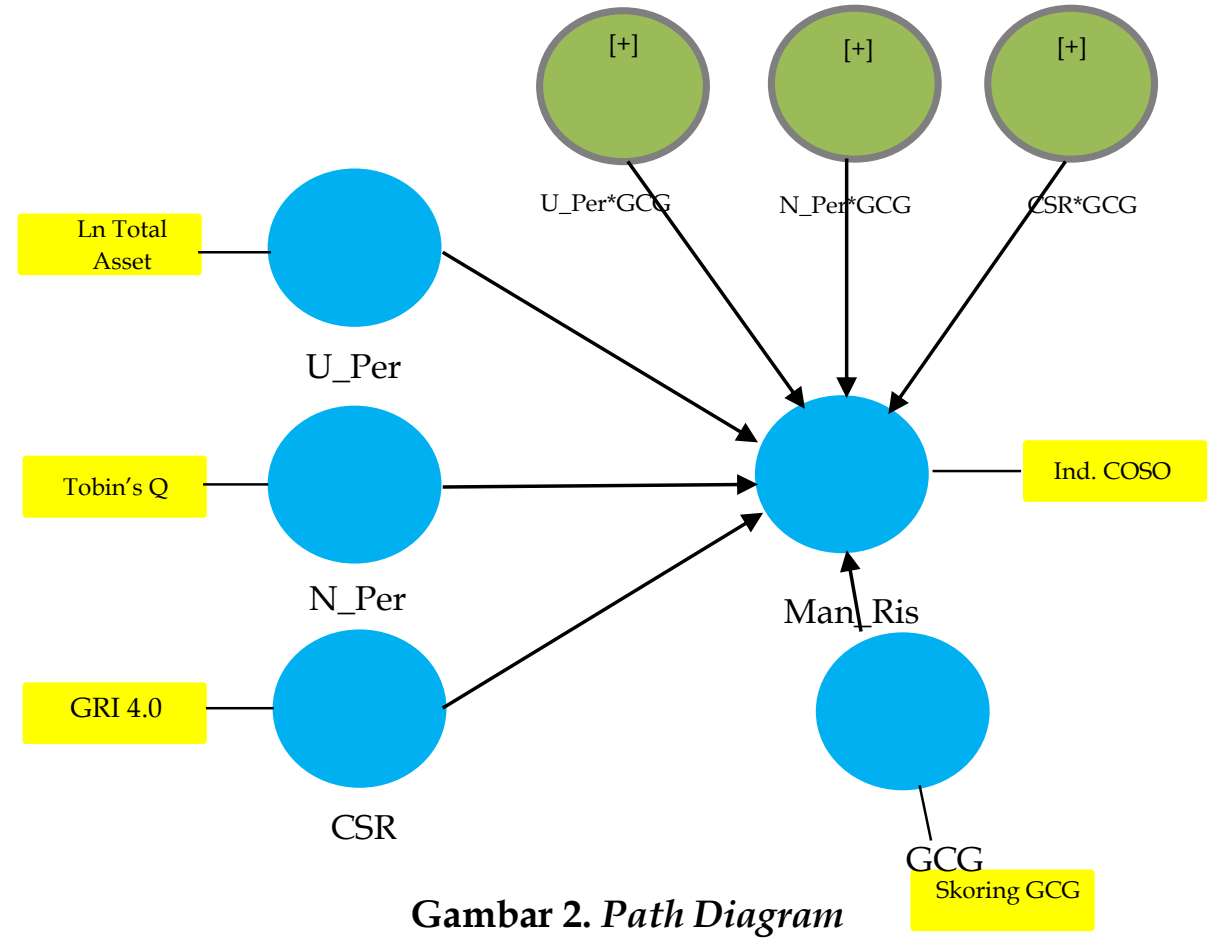

Sumber : Data Penelitian, 2019 


\section{HASIL DAN PEMBAHASAN}

Uji linieritas dilakukan sebelum melihat hubungan antar variabel dalam suatu model. Hasil pengujian asumsi nampak pada Tabel 3.

\section{Tabel 3. Uji Linieritas}

\begin{tabular}{|c|c|c|c|c|c|c|}
\hline $\begin{array}{l}\text { Hubungan } \\
\text { Antar } \\
\text { Variabel }\end{array}$ & Linier & Inverse & Quadratic & Cubic & Growth & Keterangan \\
\hline $\begin{array}{l}\text { U_Per -> } \\
\text { Man_Ris }\end{array}$ & 0,000 & 0,000 & 0,000 & 0,000 & 0,000 & Linier \\
\hline $\begin{array}{l}\text { N_Per -> } \\
\text { Man_Ris }\end{array}$ & 0,000 & & 0,000 & 0,000 & 0,000 & Linier \\
\hline $\begin{array}{c}\text { CSR -> } \\
\text { Man_Ris }\end{array}$ & 0,000 & & 0,000 & 0,000 & 0,000 & Linier \\
\hline $\begin{array}{l}\text { GCG -> } \\
\text { Man_Ris }\end{array}$ & & & & 0,015 & & Linier \\
\hline $\begin{array}{c}\text { U_Per*GCG - } \\
>\text { Man_Ris }\end{array}$ & & & 0,022 & & & Linier \\
\hline $\begin{array}{l}\text { N_Per -> } \\
\text { Man_Ris }\end{array}$ & 0,000 & & 0,000 & 0,000 & 0,000 & Linier \\
\hline $\begin{array}{c}\mathrm{CSR}^{*} \mathrm{GCG}-> \\
\text { Man_Ris }\end{array}$ & 0,000 & & 0,000 & 0,000 & 0,000 & Linier \\
\hline
\end{tabular}

Sumber : Data Penelitian, 2019

Uji linieritas menunjukan bahwa seluruh variabel menunjukan bahwa seluruh persamaan dalam pengujian linieritas menunjukan nilai signifikansi $<0,05$ yang artinya ketujuh model jalur dalam model penelitian memnuhi asumsi linieritas.

Hasil evaluasi inner model untuk melihat $\mathrm{R}^{2}$ disajikan dalam Tabel 4.

Tabel 4. Nilai $\mathbf{R}$ Square $\left(\mathbf{R}^{2}\right)$

\begin{tabular}{cc}
\hline Konstruk & R Square $\left(\boldsymbol{R}^{2}\right)$ \\
\hline Manajemen Risiko & 0,123
\end{tabular}

Sumber : Data Penelitian, 2019

Berdasarkan Tabel 4. diketahui bahwa nilai $\mathrm{R}^{2}$ yang diperoleh adalah sebesar 0,123 atau 12,3\% yang memiliki arti bahwa 12,3\% variabel manajemen risiko sebagai variabel endogen dipengaruhi ukuran perusahaan, nilai perusahaan dan Pengungkapan CSR sebagai variabel eksogen dan GCG sebagai variabel moderasi. Sisanya sebesar 87,7 \% dipengaruhi oleh variabel lain diluar model yang dibangun didalam penelitian ini.

Nilai Effect Size $\left(\mathrm{F}^{2}\right)$ digunakan untuk mengetahui kebaikan model penelitian. Ghozalli dan Latan (2015:78) menyebutkan bahwa $\mathrm{F}^{2}$ meliputi 0,02 (Kecil), 0,15 (Menengah) dan 0,35 (besar). Adapun nilai $\mathrm{F}^{2}$ dalam penelitian ini disajikan pada Tabel 5 . 
Tabel 5. Nilai Effect Size $\left(F^{2}\right)$

\begin{tabular}{ccc}
\hline Keterangan & Nilai & Kebaikan Model \\
\hline U_Per $>>$ Man_Ris & 0,077 & Menengah \\
N_Per $>$ Man_Ris & 0,003 & Kecil \\
CSR -> Man_Ris & 0,011 & Kecil \\
GCG $->$ Man_Ris & 0,014 & Kecil \\
U_Per*GCG $>>$ Man_Ris & 0,002 & Kecil \\
N_Per*GCG $>$ Man_Ris & 0,001 & Kecil \\
CSR*GCG $->$ Man_Ris & 0,007 & Kecil \\
\hline
\end{tabular}

Sumber : Data Penelitian, 2019

Dari Tabel 5. dapat dilihat bahwa ukuran perusahaan (U_Per) memiliki nilai $\mathrm{F}^{2}$ yang digolongkan menengah karena memiliki nilai diatas 0,02 . Sedangkan nilai perusahaan (N_Per), pengungkapan Corporate Social Responsibility (CSR), Good Corporate Governance (GCG), interkasi ukuran perusahaan dan GCG (U_Per*GCG), interaksi nilai perusahaan dan GCG (N_Per*GCG) dan interaksi pengungkapan CSR dan GCG (CSR ${ }^{*}$ GCG) memiliki nilai dibawah 0,02 sehingga dikatakan model tersebut masuk didalam kategori lemah atau kecil.

Hasil pengujian PLS yang dilakukan pada model penelitian menunjukan bahwa H1, H3 dan H6 diterima karena nilai t-statistiknya lebih besar dati nilai ttable 1,96 (p-value lebih kecil dari 0,05), sedangkan H2, H4 dan H5 ditolak. Analisis terhadap hasil output PLS dengan melihat Tabel 6.

Tabel 6. Path Coeficients (Mean, STDEV, T-Value)

\begin{tabular}{|c|c|c|c|}
\hline $\begin{array}{c}\text { Hubungan } \\
\text { Antar Variabel }\end{array}$ & Original Sampel $(\mathrm{O})$ & T Statistic $(\mid \mathrm{O} /$ STDEV $\mid)$ & P-Values \\
\hline $\begin{array}{l}\text { U_Per -> } \\
\text { Man_Ris }\end{array}$ & 0,295 & 5,258 & 0,000 \\
\hline $\begin{array}{l}\text { N_Per -> } \\
\text { Man_Ris }\end{array}$ & 0,055 & 1,103 & 0,270 \\
\hline CSR -> Man_Ris & 0,110 & 2,054 & 0,040 \\
\hline $\begin{array}{c}\text { U_Per*GCG -> } \\
\text { Man_Ris }\end{array}$ & $-0,048$ & 0,743 & 0,458 \\
\hline $\begin{array}{c}\text { N_Per*GCG -> } \\
\text { Man_Ris }\end{array}$ & 0,030 & 0,635 & 0,526 \\
\hline $\begin{array}{c}\text { CSR }^{*} \text { GCG -> } \\
\text { Man_Ris }\end{array}$ & 0,103 & 2,160 & 0,031 \\
\hline
\end{tabular}

Sumber : Data Penelitian, 2019

Semakin besar ukuran sebuah perusahaan maka manajemen risiko yang ada di dalam perusahaan juga semakin kuat artinya bahwa ukuran perusahaan yang tinggi akan membuat agency cost yang mengancam perusahaan juga semakin tinggi. Pada teori keagenan telah dijelaskan terdapat satu asumsi yaitu asimetri informasi, di mana asumsi ini menyatakan bahwa agent memiliki lebih banyak informasi daripada principal. Menurut Jensen \& Meckling (1976), dengan adanya asimetri informasi maka risiko akan munculnya dua masalah yaitu moral hazard dan adverse selection akan semakin meningkat. Masalah keagenan tentu dapat diatasi namun akan menimbulkan biaya keagenan (agency cost) yang ditanggung 
oleh principal maupun agent. Penerapan manajemen risiko sendiri dapat meminimalisir adanya biaya keagenan yang tinggi. Hasil penelitian ini didukung oleh hasil penelitian yang dilakukan oleh Sanusi et al., (2017) yang menyatakan semakin besar ukuran perusahaan maka manajemen risiko yang dilakukan oleh perusahaan juga semakin meningkat karena potensi munculnya agency cost juga semakin tinggi.

Perubahan terhadap nilai perusahaan ternyata tidak berpengaruh terhadap manajemen risko yang dilakukan oleh perusahaan. Artinya naik turunnya nilai perusahaan hal ini tidak akan mempengaruhi manajemen dalam hal melakukan manajemen risiko dikarenakan manajemen merasa bahwa investor hanya akan memperhatikan tingkat pengembalian yang akan diterimanya tanpa memikirkan risiko yang akan dihadapi oleh perusahaan. Pada stakeholder theory yang diungkapkan oleh Clarkson (1994) dijelaskkan bahwa terdapat pihak yang akan mempengaruhi dan dipengaruhi oleh keputusan dan strategi yang akan di lakukan oleh sebuah perusahaan, dengan kata lain nilai perusahan yang terbentuk sudah cukup untuk untuk mempengaruhi stakeholder yang berhubungan dengan perusahaan. Suatu perusahaan akan berusaha untuk memaksimalkan nilai perusahaan yang ditandai dengan naiknya harga saham. Tujuan utama dari didirikannya perusahaan adalah untuk mencapai keuntungan atau laba yang sebesar-besarnya (Zarlia \& Salim, 2014). Hasil dari penelitian didukung temuan dari penelitian yang dilakukan oleh Milos et al., (2016) yang menemukan bahwa investor tidak akan terlalu memikirkan manajemen risiko yang dilakukan oleh perusahaan dalam menghadapi risiko yang timbul dari besar kecilnya nilai perusahaan.

Semakin tinggi pengungkapan CSR yang dilakukan oleh perusahaan maka manajamen risiko yang dilakukan oleh perusahaan juga semakin meningkat. Artinya, bahwa meningkatnya pengungkapan CSR yang dilakukan oleh perusahaan maka risiko profitabilitas yang diahadapi oleh perusahaan juga semakin meningkat sehingga perusahaan perlu meminimalisir risiko tersebut dengan melakukan manajemen risiko. Dalam teori stakeholder telah menjelaskan bahwa perusahaan tidak hanya beroperasi untuk pencapaian tujuannya saja tetapi harus memberikan manfaat bagi para stakeholder perusahaan. Dengan kata lain stakeholder adalah pihak yang mempengaruhi atau akan dipengaruhi oleh keputusan dan strategi perusahaan. Berkaitan dengan hal tersebut, maka dibentuklah sebuah mekanisme tanggung jawab sosial yang memperhatikan kepentingan pihak pihak diluar perusahaan dengan melakukan pengungkapan tanggung jawab sosial dan lingkungan atau Corporate Social Responsibility (CSR). Akan tetapi pengungkapann CSR yang dianggap sebagai tanggung jawab perusahaan ini ternyata memiliki risiko tersendiri bagi perusahaan yaitu resiko profitabilitas sehingga untuk mengelola risiko tersebut perusahaan dapat meningkatkan manajemen risikonya (Adiatma, 2016).

Hasil analisis SmartPLS 3.0 untuk efek moderasi disajikan melalui nilai total effect pada Tabel 7. 
Tabel 7. Nilai Total Effect

\begin{tabular}{|c|c|c|c|c|c|}
\hline $\begin{array}{l}\text { Hubungan } \\
\text { Antar } \\
\text { Variabel }\end{array}$ & $\begin{array}{c}\text { Original } \\
\text { Sampel }(O)\end{array}$ & $\begin{array}{c}\text { T Statistik } \\
(|O / S T D E V|)\end{array}$ & P-Values & $\begin{array}{c}\text { Efek } \\
\text { Moderasi }\end{array}$ & $\begin{array}{c}\text { Tipe } \\
\text { Moderasi }\end{array}$ \\
\hline $\begin{array}{l}\text { GCG -> } \\
\text { Man_Ris }\end{array}$ & $-0,125$ & 2,045 & 0,041 & Signifikan & \\
\hline $\begin{array}{c}\text { U_Per }{ }^{*} G C G \text { - } \\
>\text { Man_Ris }\end{array}$ & $-0,048$ & 0,743 & 0,487 & $\begin{array}{c}\text { Tidak } \\
\text { Signifikan }\end{array}$ & $\begin{array}{c}\text { Predictor } \\
\text { Moderating }\end{array}$ \\
\hline $\begin{array}{c}\text { N_Per*GCG - } \\
>\text { Man_Ris }\end{array}$ & 0,030 & 0,635 & 0,292 & $\begin{array}{c}\text { Tidak } \\
\text { Signifikan }\end{array}$ & $\begin{array}{c}\text { Predictor } \\
\text { Moderating }\end{array}$ \\
\hline $\begin{array}{c}\text { CSR }^{*} \text { GCG -> } \\
\text { Man_Ris }\end{array}$ & 0,103 & 2,160 & 0,042 & Signifikan & $\begin{array}{c}\text { Quasi } \\
\text { Moderating }\end{array}$ \\
\hline
\end{tabular}

Sumber : Data Penelitian, 2019

Pengujian hipotesis keempat (H4) yang menyatakan bahwa variabel GCG akan memperkuat pengaruh antara ukuran perusahaan terhadap manajemen risiko tidak dapat diterima karena hasil pengujian hipotesis dan nilai total effect yang telah dilakukan menunjukan bahwa pengaruh interaksi ukuran perusahaan dan GCG dengan manajemen risiko memiliki nilai t-statistic 0,734 < 1,96 (t-table) selain itu nilai p-value pada hubungan antara interaksi ukuran perusahaan dengan GCG dan dengan manajemen risiko sebesar 0,487 lebih besar dari nilai alpha sebesar 0,050. Hal ini berarti klasifikasi moderasi yang terjadi adalah tipe predictor moderating, yaitu tipe moderasi dimana variabel GCG hanya berperan sebagai variabel prediktor dan tidak berhasil untuk memoderasi pengaruh akan kuat lemahnya ukuran perusahaan terhadap manjemen risiko. Artinya, besar kecilnya nilai GCG yang dimilki oleh sebuah perusahaan belum mampu untuk memperkuat atau memperlemah pengaruh ukuran perusahaan terhadap manajemen risiko. Hasil dari penelitian ini tidak mendukung penelitian yang dilakukan oleh Chen et al., (2006) dan Ardiansyah (2014) yang menyatakan bahwa GCG dapat memperkuat kontrol terhadap ukuran perusahaan sehingga manajemen risiko juga semakin meningkat. Akan tetapi hasil dari penelitian ini didukung hasil dari penelitian yang dialukan oleh Guna (2010) yang menyatakan bahwa GCG tidak dapat memberikan pengaruh terhadap hubungan antara ukuran perusahaan dan manajemen risiko dikarenakan komponen komponen GCG yang menjadi bagian dari GCG gagal dan belum mampu untuk menjalankan mekanisme prinsip prinsip GCG yang seharusnya dilakukan. Dalam agency theory Jensen \& Meckling, (1976) sebelumnya telah dijelaskan bahwa akibat dari adanya perbedaan kepentingan dari agent dan principal kemudian ditambah dengan adanya asimetri informasi maka hal ini akan memunculkan sebuah risiko munculnya agency cost. Selain risiko agency cost, pada umumnya perusahaan yang lebih besar akan memiliki aktivitas bisnis yang lebih kompleks yang akan menyebabkan kemungkinan risiko-risiko yang akan diterima oleh perusahaan tersebut akan lebih besar dibanding perusahaan yang lebih kecil Dzakawali (2017). Semakin besar risiko yang mengancam sebuah perusahaan maka seharusnya manajemen risiko yang dijalankan oleh perusahaan juga semakin meningkat dan hal tersebut dapat dibantu dengan menjalankan mekanisme GCG akan tetapi hal 
ini tidak akan bisa berjalan apabila komponen kompone yang manjadi bagian dari GCG tidak mampu atau gagal dalam melaksanakan mekanisme GCG.

Pengujian hipotesis kelima (H5) yang menyatakan bahwa variabel GCG akan memperkuat pengaruh antara nilai perusahaan terhadap manajemen risiko tidak dapat diterima karena hasil pengujian hipotesis dan nilai total effect yang telah dilakukan menunjukan bahwa pengaruh interaksi nilai perusahaan dan GCG dengan manajemen risiko memiliki nilai t-statistic 0,635 <1,96 (t-table) selain itu nilai p-value pada hubungan antara interaksi ukuran perusahaan dengan GCG dan dengan manajemen risiko sebesar 0,292 lebih besar dari nilai alpha sebesar 0,050. Hal ini berarti klasifikasi moderasi yang terjadi adalah tipe predictor moderating, yaitu tipe moderasi dimana variabel GCG hanya berperan sebagai variabel prediktor dan belum berhasil untuk memoderasi pengaruh akan kuat lemahnya nilai perusahaan terhadap manjemen risiko. Artinya, besar kecilnya nilai GCG yang dimilki oleh sebuah perusahaan belum mampu untuk memperkuat atau memperlemah pengaruh nilai perusahaan terhadap manajemen risiko. Hasil dari penelitian ini belum berhasil didukung hasil penelitian yang dilakukan oleh Syafitri et al., (2018) yang menyatakan bahwa GCG memiliki peran penting terhadap nilai perusahaan untuk mengendalikan perusahaan agar mencapai keseimbangan antara kekuatan serta kewenangan perusahaan dalam memberikan pertanggungjawaban kepada pihak-pihak yang berkepentingan. Akan tetapi hasil dari penelitian ini didukung oleh hasil dari penelitian yang dilakukan oleh Suparsa et al., (2017) yang menyatakan bahwa GCG tidak dapat memoderasi pengaruh nilai perusahaan terhadap manajemen risiko dikarenakan investor belum mampu menggunakan informasi GCG sebagai dasar dalam menilai kinerja sebuah perusahaan sehingga GCG dianggap tidak memiliki pengaruh terhadap manajemen risiko. Pada stakeholder theory yang diungkapkan oleh Clarkson (1994), dijelaskkan bahwa keptusan dan strategi yang dilakukan oleh perusahaan sudah pasti akan memunculkan pihak yang mempengaruhi dan pihak yang dipengruhi. Nilai perusahaan itu akan menjadi dasar persepsi investor terhadap tingkat keberhasilan perusahaan. Tentu saja dengan perusahaan menjalankan mekanisme GCG maka hal ini akan menjadi nilai tambah bagi kenerja perusahaan akan tetapi karena investor yang lebih mementingkan investasi untuk jangka pendek maka mekanisme GCG yang dijalankan didalam perusahaan tidak akan memiliki pengaruh terhadap nilai perusahaan.

Pengujian hipotesis keenam (H6) yang menyatakan bahwa variabel GCG akan memperkuat pengaruh antara pengungkapan CSR terhadap manajemen risiko diterima karena hasil pengujian hipotesis dan nilai total effect yang telah dilakukan menunjukan bahwa pengaruh interaksi pengungkapan CSR dan GCG dengan manajemen risiko memiliki nilai t-statistic 2,160 > 1,96 (t-table) selain itu nilai p-value pada hubungan antara interaksi ukuran perusahaan dengan GCG dan dengan manajemen risiko sebesar 0,042 lebih kecil dari nilai alpha sebesar 0,050. Hal ini berarti GCG berhasil memoderasi pengaruh antara pengungkapan CSR terhadap manajemen risiko.

Hasil temuan dari penelitian ini berhasil mendukung pernyataan Komite Nasional Corporate Governance dimana GCG menjadi sarana perusahaan untuk meningkatkan mekanisme transparansi, akuntabilitas, responsibilitas, 
independensi, serta kewajaran dan kesetaraan keseluruh komponen perusahaan dan hasil dari penelitian ini juga didukung oleh hasil temuan dari Habbash (2015) bahwa GCG telah berevolusi sebagai sarana yang mengakomodasi hal yang dulunya tidak dianggap perlu yaitu hubungan bisnis lingkungan dan hubungan bisnis masyarakat dalam hal ini pengungkapan CSR sebagai tanggung jawab kepada sosial dan lingkungan.

Hasil temuan dari hipotesis keenam (H6) ini juga memperkuat konsep stakeholder theory yang menjelaskan bahwa perusahaan pada saat sekarang tidak lagi hanya beroperasi untuk memenuhi kepentingan perusahaan saja tetapi tidak lupa juga harus memberikan manfaat bagi para stakeholder perusahaan. Tipe moderasi yang terjadi adalah quasi moderating (moderasi semu), merupakan variabel moderasi yaitu GCG mampu memperkuat pengaruh anatara pengungkapan CSR dengan manajemen risiko. Dimana GCG mampu berinteraksi dengan pengungkapan CSR sekaligus menjadi variabel prediktor, artinya keberadaan GCG bisa saja memperkuat pengaruh pengungkapan CSR dengan manajemen risiko dimana dengan meningkatnya mekanisme GCG yang dilakukan oleh perusahaan maka hal ini akan membuat perusahaan semakin banyak mengungkapkan CSR dan pada akhirnya akan meningkatkan juga manajemen risiko yang dilakukan oleh perusahaan.

\section{SIMPULAN}

Ukuran perusahaan memiliki pengaruh positif signifikan terhadap manajemen risiko. Hal ini menunjukan bahwa semakin besar ukuran sebuah perusahaan maka semakin meningkat pula manajemen risiko. Hasil dari penelitian ini sesuai temuan penelitian yang dilakukan oleh Sanusi et al., (2017) yang menyatakan bahwa semakin besar ukuran perusahaan maka semakin meningkat pula manajemen risiko yang dilakukan oleh perusahaan untuk meminimalisir risiko munculnya agency cost.

Nilai perusahaan tidak memiliki pengaruh terhadap manajemen risiko. Hal ini menunjukan besar kecilnya nilai yang dimiliki perusahaan tidak akan mempengaruhi manajemen risiko yang dijalankan oleh sebuah perusahaan. Hasil dari penelitian ini didukung oleh temuan penelitian yang dilakukan oleh Milos et al., (2016) yang menyatakan bahwa nilai perusahaan tidak akan mempengaruhi manajemen risiko yang dilakukan oleh perusahaan dikarenakan manajemen menganggap investor hanya akan memperdulikan jumlah pengembalian yang akan mereka terima tanpa memikirkan risiko yang akan ditanggung oleh perusahaan.

Pengungkapan CSR memiliki pengaruh positif signifikan terhadap manajemen risiko. Hal ini menunjukan bahwa semakin tinggi pengungkapan CSR yang dilakukan oleh perusahaan maka semakin meningkat pula manajemen risiko perusahaan. Hasil dari penelitian ini telah didukung oleh hasil temuan dari penelitian yang dilakukan oleh Adiatma (2016) yang menyatakan bahwa semakin tinggi pengungkapan yang dilakukan oleh perusahaan maka semakin tinggi pula manajemen risiko yang dialkukan oleh perusahaan untuk mengelola dan meminimalisir risiko profitabilitas yang mengancam perusahaan.

GCG berpengaruh negatif tetapi tidak signifikan dalam memperlemah pengaruh ukuran perusahaan terhadap manajemen risiko. Hal ini menunjukan 
bahwa Good Corporate Governance (GCG) belum berhasil menjadi variabel moderasi. Hasil dari penelitian ini sesuai hasil temuan penelitian yang dilakukan oleh Guna (2010) yang menyatakan bahwa GCG tidak mampu memberikan pengaruh dikarenakan komponen GCG yang gagal dalam melaksanakan mekanisme GCG.

GCG berpengaruh positif tetapi tidak signifikan dalam memperkuat pengaruh nilai perusahaan terhadap manajemen risiko. Hal ini menunjukan bahwa GCG belum berhasil menjadi variabel moderasi. Hasil dari peneltian ini telah didukung oleh hasil penelitian yang dilakukan oleh Suparsa et al., (2017) yang menyatakan bahwa GCG tidak dapat memoderasi pengaruh nilai perusahaan terhadap manajemen risiko dikarenakan manajemen menganggap bahwa GCG belum mampu dijadikan dasar dalam menilai kinerja sebuah perusahaan sehingga GCG dianggap tidak mampu untuk memoderasi pengaruh nilai terhadap manajemen risiko.

GCG berpengaruh positif signifikan dalam memperkuat pengaruh pengungkapan CSR terhadap manajemen risiko. Hal ini menunjukan bahwa GCG telah berhasil menjadi variabel moderasi. Hasil dari penelitian ini didukung oleh penelitian yang dilakukan oleh Habbash (2016) yang menyatakan bahwa GCG telah menjadi sarana yang mengakomodasi hal yang dulunya tidak dianggap perlu yaitu hubungan bisnis lingkungan dan hubungan bisnis masyarakat dalam hal ini pengungkapan CSR sebagai tanggung jawab kepada sosial dan lingkungan.

Keterbatasan pada penelitian ini diharapkan dapat memberikan arah bagi penelitian mendatang. Pertama, hasil dari penelitian menunjukan bahwa variabel ukuran perusahaan, nilai perusahaan, pengungkapan CSR dan GCG hanya mampu menjelaskan variabel manajemen risiko sebesar $12,3 \%$ dan sisanya dipengaruhi oleh variabel lainnya. Saran pada peneltian selanjutnya bisa menambahkan variabel lain seperti kinerja keuangan dikarenakan kinerja keuangan dari sebuah perusahaan akan sangat berpengaruh terhadap manajemen risiko yang akan dilakukan oleh perusahaan tersebut. Kedua, pada penelitian ini sampel yang digunakan hanya berupa perusahaan sektor manufaktur, diharapkan pada penelitian selanjutnya sampel bisa berasal dari sektor perusahaan lain seperti sektor jasa, sektor agri, sektor pertambangan ataupun infrastruktur. Ketiga, untuk pengembangan penelitian ini, variabel GCG bisa digunakan sebagai variabel bebas atau intervening dikarenakan GCG memilki pengaruh langsung terhadap manajemen risiko.

Untuk perbaikan praktis sendiri temuan dalam penelitian ini dapat memberikan beberapa perbaikan pada penerpan manajemen risiko di dalam sebuah perusahaan. Pertama, disarakan agar pengawasan oleh stakeholder perlu untuk ditingkatkan kembali melalui pengoptimalan prinsip GCG yang telah disepakati sebelumnya seperti akuntabilitas dan transparansi didalam perusahaan.. Kedua, investor perlu memperhatikan aspek pembentuk nilai perusahaan yang lain seperti manajemen risiko ketika mempertimbangkan untuk berinvestasi didalam sebuah perusahaan. Ketiga, perusahaan harus mampu mengungkapkan CSR seefisien mungkin dan sesuai standar yang ada dalam hal ini perushaan bisa menggunakan standar pengungkapan CSR agar perusahaan bisa terhindar dari risiko profitabilitas. Keempat, perusahaan perusahaan sektor manufaktur yang ada di Indonesia perlu meningkatkan kembali manajemen risiko 
dengan mengimplementasikan standar manajemen risiko yang berlaku didalam Indonesia. Kelima, pihak investor seharusnya bisa lebih baik lagi dalam membaca nilai perusahaan yang dimiliki oleh perusahaan dengan membaca laporan tahunan yang dibuat oleh perusahaan dikarenakan informasi yang tersaji disana lebih lengkap dan bisa memberikan pertimbangan yang lebih baik lagi bagi investor. Keenam, kedepannya diharapkan agar perusahaan bisa menerapkan prinsip prinsip GCG seperti akuntabilitas, transparansi, responsibilitas, independensi dan kewajaran untuk membuat manajemen risiko yang dijalankan oleh perusahaan semakin baik.

\section{REFERENSI}

Adiatma, Y. (2016). Penerapan Corporate Social Responsibility (CSR) pada Asahitmas Glass Tbk.

Akbar, A. (2018). 4 Pelajaran Bisnis yang Bisa Kamu Petik dari Pailitnya PT Sariwangi. Retrieved March 13, 2019, from https://www.moneysmart.id/ada-empat-pelajaran-bisnis-yang-sangatberharga-dari-pailitnya-pt-sariwangi/

Andhari, P., \& Made, I. (2017). Pengaruh Pengungkapan Corporate Social Responsibility, Profitabilitas, Inventory Intensity, Capital Intensity dan Leverage pada Agresifitas Pajak. E-Jurnal Akuntansi Universitas Udayana, 18(3), 2115-2142.

Ardiansyah, L., \& Adnan, M. (2014). Faktor Faktor yang Mempengaruhi Luas Pengungkapan Enterprise Risk Management. Jurnal Ekonomi, Manajemen, Dan Akuntansi, 18(3), 89-105.

Beasley, M. S., Clune, R., \& Hermanson, D. R. (2005). Enterprise risk management: An empirical analysis of factors associated with the extent of implementation. Journal of Accounting and Public Policy, 24(6), 521-531.

Berzkalne, I., \& Zelgave, E. (2014). Intellectual Capital and Company Value. Procedia - Social and Behavioral Sciences, 110(2014), 887-896.

Chen, G., Gao, M. F., \& Rui, O. M. (2006). Ownership structure, corporate governance and Fraud: Evidence from China. Journal of Corporate Finance, 12(3), 424-448.

Clarkson, M. (1994). A Risk-Based Model Stakholder Theory. Proceeding of the and Toronto Conference on Stakeholder Theory, Center for Corporate Social Performance and Ethics University Of Toronto.

COSO. (2018). ERM Integrated Framework. Retrieved March 14, 2019, from https://www.coso.org/Pages/erm-integratedframework.aspx.

CRSM. (2012). Center Of Risk Management Studies: GCG dan Manajemen Risiko. Retrieved March 11, 2019, from http://crmsindonesia.org/

CRSM. (2013). Center Of Risk Management Studies: Penilaian Tingkat Kemantangan Manajemen Risiko Di Organisasi Di Indonesia. Retrieved March 11, 2019, from http://crmsindonesia.org/publications/penilaiantingkat-kematangan-manajemen-risiko-di-organisasi-di-indonesia/

CRSM. (2018). Center Of Risk Management Studies: Survei Manajemen Risiko 2018. Retrieved March 11, 2019, from http://crmsindonesia.org/

Desender, K. (2007). On the Determinants of Enterprise Risk Management Implementation. Enterprise IT Governance, Business Value and Performance 
Measurement. https:/ / doi.org/10.4018/978-1-60566-346-3.ch006

Devi, S., Budiasih, I. G. N., \& Bedera, I. D. N. (2017). Pengaruh Pengungkapan Enterprise Risk Management dan Pengungkapan Intellectual Capital Terhadapn Nilai Perusahaan. Jurnal Akuntansi Dan Keuangan Indonesia, 14(1), 20-45.

Dzakawali, M. G., Muhammad, R. N., \& Siska, P. Y. (2017). Pengaruh Ukuran Dewan Komisaris, Ukuran Perusahaan, dan Konsentrasi Kepemilikan terhadap Pengungkapan Enterprise Risk Management. E-Proceeding of Management, 4(3), 2597-2603.

Eckles, D. L., Robert, E. H., \& Steve, M. . (2014). The Impact of Enterprise Risk Management on the Marginal Cost of Reducing Risk: Evidence From the Insurance Industry. Jurnal of Banking \& Finance, 43(C), 247-261.

Effendi, M. A. (2016). The Power of Good Corporate Governance (2nd ed.). Jakarta: Salemba Empat.

Eisenhardt, K. M. (1989). Agency theory; an assessment and review. Academy of Management Review, 14(1), 57-74.

Farrell, M., \& Gallagher, R. (2015). The Valuation Implication of Enterprise Risk Management Maturity. The Journal Risk and Insurance, 82(3), 625-657.

Ghozali, I., \& Chariri, A. (2007). Teori Akuntansi. Semarang: Badan Penerbit Universitas Diponegoro.

Guna, W. I., \& Herawaty, A. (2010). Pengaruh Mekanisme Good Corporate Governance, Independensi Auditor, Kualitas Audit dan Faktor Lainnya terhadap Manajemen Laba. Jurnal Bisnis Dan Akuntansi, 12(1), 53-68.

Habbash, M. (2016). Corporate governance and corporate social responsibility disclosure: evidence from Saudi Arabia. Social Responsibility Journal, 12(4), 740-754.

Hanafi, M. M. (2014). Risiko, Proses Manajemen Risiko, dan Enterprise Risk Management. Modul Online.

Jensen, \& Meckling. (1976). The Theory of The Firm: Manjerial Behavior, Agency cost and Ownership Structure. Journal of Financial and Economics, 3(1976), 305360 .

Khumairoh, N. A., \& Agustina, L. (2017). The Roles of The Board of Commissioner in Moderating Factors Affeting The Disclosure Of Enterprise Risk Management. Accounting Analysis Journal, 6(3), 445-457.

Kurniasih, T., \& Maria, M. (2013). Pengaruh Return On Assets, Leverage, Corporate Governance, Ukuran Perusahaan Dan Kompensasi Rugi Fiskal Pada Tax Avoidance. Buletin Studi Ekonomi, 18(1), 1-84.

Lee, S., Young, K. K., \& Kim, K. (2016). Corporate Governance, Firm Risk, and Corporate Social Responsibility : Evidance from Korean Firms. The Journal of Applied Business Research, 32(1), 305-316.

Mason, C., \& John, S. (2014). Embedding Corporate Social Responsibility in Corporate Governance: A Stakeholder Systems Approach. Journal of Business Ethics, 119(1), 77-86.

Milos, S. D., Mesin M.Z., Sevic, Z., \& Marc, M. (2016). Does enterprise risk management influence market value - A long-term perspective. Risk Management, 18(2), 18-65.

Prabudi, I. M., \& W., S. I. (2015). Loyalitas Karyawan terhadap Prestasi Kerja. 
Journal of Business Ethics, 8(1), 192-208.

Prasetyoni, F. (2013). Pengaruh Ukuran Perusahaan, Leverage, Price Earning Ratio dan Profitabilitas terhadap Nilai Perusahaan. Jurnal Ilmu Manajemen, 1(1), 183-196.

Ruwita, C. (2012). Analisis Pengaruh Karakteristik Perusahaan dan Corporate Governance Terhadap Pengungkapan Risiko Perusahaan (Studi Empiris Pada Perusahaan-Perusahaan Manufaktur yang Terdaftar di Bursa Efek Indonesia).

Sanusi, M. Z., N., S. M., N.S., R., \& Harjito, A. (2017). Effects of Corporate Governance Structures on Enterprise Risk Management Practices in Malaysia. International Journal of Economics and Financial Issues, 7(1), 6-13.

Sugiyono. (2013). Metode Penelitian Bisnis. Bandung: Alfabeta.

Sulistyaningsih. (2016). Analisis Faktor Faktor yang Mempengaruhi Risk Management Disclosure. Riset Akuntansi Dan Keuangan Indonesia, 1(1), 1-11.

Suparsa, I. M. J., Ramantah., I. W., \& Badera, I. D. N. (2017). Kemampuan Good Corporate Governance dalam Memoderasi Pengaruh Intellectual Capital Disclosure dan Reputasi Auditor pada Nilai Perusahaan. E-Journal Ekonomi Dan Bisnis Universitas Udayana, 6(2), 505-532.

Syafitri, T., Nuzula., N. F., \& Nuraily, F. (2018). Pengaruh Good Corporate Governance Terhadap Perusahaan (Studi pada Peruashaan Industri Sub Sektor logam dan Sejenisnya yang Terdaftar Di BEI periode 2012-2016). Jurnal Administrasi Dan Bisnis, 16(1), 118-126.

Wahidahwati. (2012). The Influence Of Financial Policies On Earning Management, Moderated By Good Corporate Governance. Jurnal Ekonomi Dan Keuangan, 16(4), 507-522.

Wartakota.tribunnews. (2018). Sejarah dan Kronologi The Celup Sariwangi Dinyatakan Bangkrut setelah 56 Tahun Berdiri. Retrieved March 14, 2018, from http://wartakota.tribunnews.com/2018/10/18/sejarah-dankronologi-teh-celup-sariwangi-dinyatakan-bangkrut-setelah-56-tahunberdiri.

Zarlia, J., \& Salim, H. (2014). Analisis Pengaruh Corporate Social Responsibility dan Profitabilitas terhadap Nilai Perusahaan: Studi Empiris pada Perusahaan Manufaktur yang Terdaftar di Bursa efek Indonesia Tahun 2013. Jurnal Manajemen, 11(2), 38-55. 